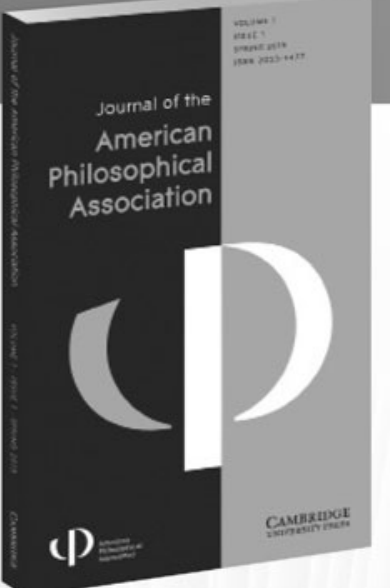

\title{
Journal of the American Philosophical Association
}

Editor-in-Chief: John Heil,

Washington University in St. Louis

Why submit to the Journal of the APA?

- Unique journal publishing groundbreaking work in every area of philosophy on behalf of the world's largest and most influential philosophical society

- Global dissemination of articles

- The largest circulation base - including more than 9,000 members of the APA - of any philosophy journal

- Online article submission

- Commitment to fast turnaround for submissions and timely publication of accepted papers

- State-of-the-art online hosting on Cambridge Journals Online

\section{Submit papers to journals.cambridge.org/apa-submit}




\section{CAMBRIDGE JDURNALS}

\section{Hegel Bulletin}

Published for the Hegel Society of Great Britain

\section{Editor}

Katerina Deligiorgi, University of Sussex, UK

Hegel Bulletin is a leading English language journal for anyone interested in Hegel's thought, its context, legacy and contemporary relevance. The Bulletin aims to promote high quality contributions in the field of Hegel studies which is broadly construed to include all aspects of Hegel's thought, and its relation and relevance to the history of philosophy; Hegelian contributions to all aspects of current philosophical enquiry; German and British Idealism, Marx and Marxism, Critical Theory, American Pragmatism; and studies in the reception history of Hegel and German Idealism.

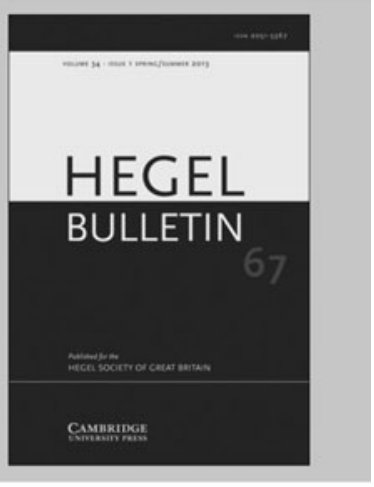

\section{Hegel Bulletin}

is available online at:

http://journals.cambridge.org/hgl

\section{Customer Services}

\section{Americas:}

Phone +1 (845) 3537500

Fax +1 (845) 3534141

Email

subscriptions_newyork@cambridge.org

\section{Rest of world:}

Phone + $44(0) 1223326070$

$\mathrm{Fax}+44(0) 1223325150$

Email journals@cambridge.org

\section{Free email alerts}

Keep up-to-date with new material - sign up at

journals.cambridge.org/hgl-alerts 


\section{Religious Studies}

An International Journal for the Philosophy of Religion

Editor

Robin Le Poidevin, University of Leeds, UK

Religious Studies is an international journal devoted to the problems of the philosophy of religion as they arise out of classical and contemporary discussions and from varied religious traditions. Space is devoted to articles, of which more than 25 are published each year, and the journal also contains an extensive book review section, which includes review articles and book notes as well as normallength reviews.

\section{Price information}

is available at: http://journals.cambridge.org/res

\section{Free email alerts}

Keep up-to-date with new material - sign up at http://journals.cambridge.org/res-alerts

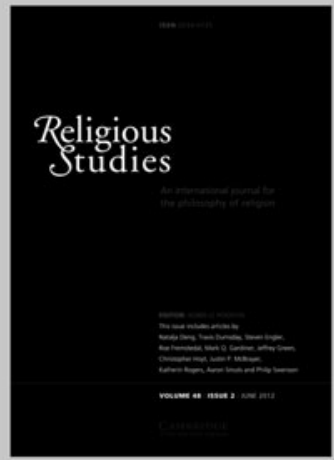

Religious Studies: An International Journal for the Philosophy of Religion

is available online at: http://journals.cambridge.org/res

To subscribe contact Customer Services

in Cambridge:

Phone +44(0)1223 326070

$\mathrm{Fax}+44(0) 1223325150$

Email journals@cambridge.org

\section{in New York:}

Phone +1 (845) 3537500

$\mathrm{Fax}+1(845) 3534141$

Email

subscriptions_newyork@cambridge.org 


\section{CAMBRIDGE JDURNALS}

\section{Social Philosophy \& Policy}

Published for The Social Philosophy and Policy Foundation

\section{Editors}

Ellen Frankel Paul, Bowling Green State University, USA Fred D. Miller, Jr., Bowling Green State University, USA Jeffrey Paul, Jr., Bowling Green State University, USA

Social Philosophy and Policy is an interdisciplinary journal with an emphasis on the philosophical underpinnings of enduring social policy debates. The issues are thematic in format, examining a specific area of concern with contributions from scholars in philosophy, economics, political science and law. While not primarily a journal of policy prescriptions, some articles in each issue will typically connect theory with practice.

\section{To subscribe contact Customer Services}

\section{Americas:}

Phone +1 (845) 3537500

$\mathrm{Fax}+1(845) 3534141$

Email

subscriptions_newyork@cambridge.org

\section{Rest of world:}

Phone +44(0) 1223326070

$\mathrm{Fax}+44(0) 1223325150$

Email journals@cambridge.org

\section{Free email alerts}

Keep up-to-date with new material - sign up at

journals.cambridge.org/register

For free online content visit: http://journals.cambridge.org/soy

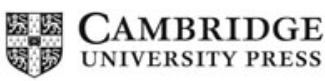




\section{Philosophy and Museums: Essays on the Philosophy of Museums}

Museums and their practices-especially those involving collection, curation and exhibition-generate a host of philosophical questions. Such questions are not limited to the domains of ethics and aesthetics, but go further into the domains of metaphysics, epistemology and philosophy of religion. Despite the prominence of museums as public institutions, they have until recently received surprisingly little scrutiny from philosophers in the Anglo-American tradition. By bringing together contributions from philosophers with backgrounds in a range of traditional areas of philosophy, this volume demonstrates how their work can enhance our understanding of museums and shed light on the philosophical questions raised by museum practices. Many of the essays in this volume make the case that the philosophy of museums is of vital concern, not only to those philosophers at work in the emerging field but also to practitioners within the museum world and to anyone who enjoys visiting museums.

Cambridge Journals Online

For further information about this journal

please go to the journal website at:

journals.cambridge.org/phs

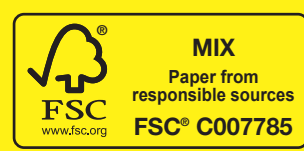

CAMBRIDGE UNIVERSITY PRESS

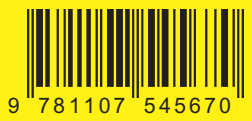

